\title{
MEDIATION IN ARMED CONFLICT
}

\author{
Marzena ŻAKOWSKA, Phd \\ m.zakowska@akademia.mil.pl \\ National Defence Faculty \\ War Studies University, Warsaw, Poland
}

\begin{abstract}
Mediation is one of the most commonly used methods for solving armed conflicts due to its flexibility allowing parties to freely decide about their participation in the mediation, the choice of a mediator, and accepting or rejecting the conditions of conflict resolution established during the mediation process.

The article looks at various approaches to mediation, leading to an indication of the nature and attributes of this method of solving armed conflicts. It also analyses the motives of the main actors of mediation - the parties' of the conflict and the mediator, which are taken into consideration when they decide to start mediation.

The research allows a better understanding of the complexity of mediation in an armed conflict. It enables the motives of the conflicting parties and mediator which have an impact on the mediation process and result to be identified.
\end{abstract}

Keywords: armed conflict, mediation, motives, conflicting parties, mediator

\section{Introduction}

Mediation has been a peaceful method used for resolving conflicts for ages, since wars started being waged. The origins of the use of mediation have been dated to China around 4000 BC. Mediation was also practiced in Ancient Greece (which 
knew the non-marital mediator as a proxenetas), and the Roman civilisation also recognised mediation (Miranda 2014, pp. 9-10; Moore 2012, pp. 35-37).

Nowadays, mediation is one of the most commonly used methods for solving armed conflicts, mainly due to its flexibility allowing parties to freely decide about their participation in the mediation, the choice of a mediator, and acceptance or rejecting the conditions of the conflict resolution established during the mediation process. An advantage of mediation is the low cost of conducting the process in comparison with the use of other methods based on third party intervention in conflict, i.e. arbitration or military intervention (cf. Bercovitch 1994, p. 10).

In literature, mediation is usually referred to as the participation and assistance of a third party in resolving a dispute between the conflicting parties. Its aim is to encourage the parties to reach a satisfactory agreement (Moore 2003, p. 15; Zartman and Touval 1985; Crocker, Hampson and All 2003, pp. 437-438; Bercovitch and Jackson 2009, p. 34). Due to the relationships between the main actors of the mediation, that is the parties to the conflict and the mediator, as well as the complex nature of the mediation process, it is described from three analytical perspectives: as an extension of the negotiation process, a third party intervention in the conflict and comprehensive conflict management.

The main factors affecting the nature, process and outcome of the mediation are the parties of the conflict and the mediator. What is also important are the motives of the mediation actors, because they affect their attitude and behaviour in the mediation process. Contemporary armed conflicts are notable for the great diversity of belligerent parties. This asymmetry, revealing itself in the area of the legal status of the conflicted parties (state and non-state actors) and the abilities and resources for conducting military operations possessed by them. The consequence of this pluralism of the parties of conflict is the high level of differentiation of the motives, which the actors present when they decide to commence the mediation.

The mediation process is directly influenced by the mediator, namely his motives for conducting the mediation, the individual range of his skills, experience in conducting negotiations and the political relations with the entity represented by him (a state or an international organisation). The role of the mediator can be performed by individuals, states, international organisations, non-governmental 
organisations, and representatives of local communities. Mediation is conducted by a so-called general mediator (designated most often due to political factors), who manages a team of co-operating individuals, including negotiators called assistant mediators, appointed to conduct negotiations on particular issues that have a significant impact on conflict resolution and experts who are often heads of various committees advising the main mediator on strategic decisions (Bercovitch and Jackson 2009).

The purpose of this article is to identify various approaches to mediation, pointing out the nature and attributes of this method for resolving armed conflict. An identification and evaluation of the key motives of the parties of the conflict and the mediator, which these actors are driven by when deciding to enter the mediation, has been carried out. In the context of this deliberation, it has been decided to answer the following questions: What are the nature and attributes of mediation in armed conflict? What are the motives of the belligerents and the mediator in mediation? It has been observed that the above mentioned actors and their motives have a significant influence on the course of the mediation process and its outcome.

\section{Mediation: nature and attributes}

Mediation is a peaceful method of armed conflicts resolution (cf. Article 33 Charter of the United Nations). In the classic view, presented by Oran Young (1967, p. 34), mediation is defined as any action taken by an actor not directly involved in the conflict, aimed at reducing or removing one or more problems occurring between the negotiating parties, which in the end should lead to establishing conditions for ending the conflict.

According to Jacek Barcik and Tomasz Srogosz (2007, pp. 435-436), mediation enables parties to the conflict to start communicating by including an independent and impartial mediator and to find a compromise solution. The role of the mediator is to convince the parties to negotiate and actively participate in the process, culminating in a proposal for the regulation of a dispute accepted by the adversaries. The proposals offered by the mediator are not obligatory for the participants. 
In the literature, mediation is also referred to as an extension of the negotiation process. This stand is presented by Christofer Moore (2003, p. 15), who emphasises that mediation consists of including a third party - a mediator in the negotiations (the so-called intermediary) who is accepted by the adversaries as an impartial and a neutral subject. Moore also claims that the mediator's role in the mediation process is focused on establishing communication between the parties, negotiating the terms of resolving the conflict with them in order to help achieve a voluntary and mutually acceptable agreement ending the war (Bühring-Uhle 1996, p. 273).

According to Grethe Nordhelle (2010, p. 27), the mediator's actions are likely to have a high risk rate that can end in failure. His/her actions resemble "a walk through a minefield where a charge can go off at any moment". Nordhelle compared mediation to a position warfare in which "both sides are on the frontline in their trenches" and the mediator "must navigate as a messenger between the missiles fired from all sides trying to reach an agreement", that is "clearing the field from these metaphorical mines".

Reaching an agreement is a key task for the mediator. Jacob Bercovitch and Karl Derouen (2004, p. 153) explained, that for this purpose, the mediator diagnoses the situation, applies various communication techniques, forms of pressure on the parties, and also rewards them for cooperation. These activities enable the intermediary to take control over the conflict context/ environment and the negotiation process.

Mediation is also defined as a form of a third party intervention in the conflict. This approach is dealt with by William Zartman and Saadia Touval (1985, pp. 437438) who argue that the purpose of mediation is to resolve a conflict in a manner acceptable for the conflicted parties and corresponding with the mediator's interests. Zartman and Touval (1985) state that mediation is a political process in which the parties are not obliged to give their consent for accepting the conditions of the dispute resolution presented to them by the mediator before it starts.

Vicenç Fisas defines mediation in a similar way, exposing the complexity of this process. He claims that it consists of a number of elements, such as establishing contacts, gathering information, setting mediation rules, identifying existing problems and the hidden goals / plans of the parties, reformulating goals, generating options for solving the problem, reaching an agreement and compromise. 
A broad spectrum of these activities allows three main stages of mediation to be determined - preparation of negotiations, negotiations and implementation of the peace agreement. At each stage, a mediator may be an individual, state, an organisation (governmental or non-governmental) or another entity ${ }^{1}$.

The comprehensive concept of mediation is presented by Jacob Bercovitch and Richard Jackson (2009, p. 34). In their opinion, mediation is the process of conflict management understood as the continuation of negotiations with the participation of an independent third party, where adversaries seek help or accept help offered by an external actor (e.g. an individual, state, organisation, or group). The purpose of mediation is to change the perception or behaviour of the parties to the conflict without resorting to physical violence or calling on a legal authority. In addition, Bercovitch and Jackson (2009) argue that the key elements of the mediation process are factors such as the parties to the conflict, the mediator, the mediation process and the context of mediation. These determine the nature, quality and effectiveness of mediation, and their analysis allows the actions taken by the mediator to be assessed and explain why some of them end successfully and some fail.

Many authors also point to the attributes that distinguish mediation from other methods based on third party interventions, which are used by the international community in armed conflict resolution. As Stefan Miłosz (1996, pp. 46-50) explains, mediation and arbitration are distinguished by the flexibility expressed in the lack of restraint of the mediator by a specific formal procedure. This flexibility facilitates the creation of conditions for starting negotiations. It allows new proposals for resolving the conflict in the negotiation process to be introduced and other peaceful methods implemented which can be helpful in regulating the conflict ${ }^{2}$. In turn, Stephen Gent and Megan Shannon (2010, pp. 366-380) emphasise that in the case of mediation, unlike arbitration, there is no obligation imposed on the conflict parties to accept the proposal of conflict resolution (cf. Folberg, Golanna, Kloppenberg, and Stipanowich 2005, p. 223; Mitchell and Powell 2011).

1 More about the mediation stages see Moore (2003, pp. 188-368).

2 Another peaceful methods of dispute resolution used in the mediation process may be e.g. good offices, fact-finding, see Bercovitch and Derouen Jr. (2004, p. 153) and Pawłowski (2007, p. 368). 
The freedom of the adversary to choose the method of resolving the dispute is the main factor distinguishing mediation from sanctions. In mediation, the parties decide to start the negotiation process voluntarily and are able to withdraw at any time. On the other hand, sanctions, as Michael Matheson (2006, pp. 65-98) claims, are a coercive measure imposed on the adversaries by an external actor in order to persuade them to abandon violence and restore peace. At the same time, the mechanism of sanctions is complex because it depends on the application of various types of restrictions in order to reduce the military activities of the conflicting parties. Among these restrictions, the pivotal role is played by economic measures (cf. Cortright and Lopez 2000; Cortright and Lopez 2002).

According to Molly Melin and Michael Koch (2009), the fundamental difference between mediation and military intervention is the use of force. Mediation is a peaceful intervention in a conflict based on communication and dialogue. By contrast, in the event of a military intervention, military force is used to resolve the conflict (Carment and James 2000).

In the analysis of mediation in an armed conflict, a contingency model of mediation (Bercovitch and Jackson 2009) is most frequently used by the reason of a comprehensive description of the structural factors of mediation and the relations between them. The model consists of three levels of conditioning: initial conditions, current conditions and consequent conditions.

Mediation is presented there as a process with such essential elements as: the context of the conflict, the course of the process of mediation and the results of the mediation. In the area of the conflict context, there are such factors as the mediator, the conflicted sides and the dispute. On the process level, the course of mediation is analysed. In the area of the result, the outcome of mediation in the context of success or failure is evaluated (Bercovitch and Jackson 2009).

Due to the significant role of the actors (the parties to the conflict and the mediator) in shaping the mediation process, it seems equitable to analyse their motives which lead them to choose mediation as a method of conflict resolution and participate in the mediation process. The nature of these motives influences the actors' behaviour in the mediation process, their specific roles, determining the areas of negotiation issues as well as determining the level of involvement 
in the mediation. Consequently, it can be argued that the motives of mediation actors play a significant role in completing the mediation process with success or failure (see Figure 1).

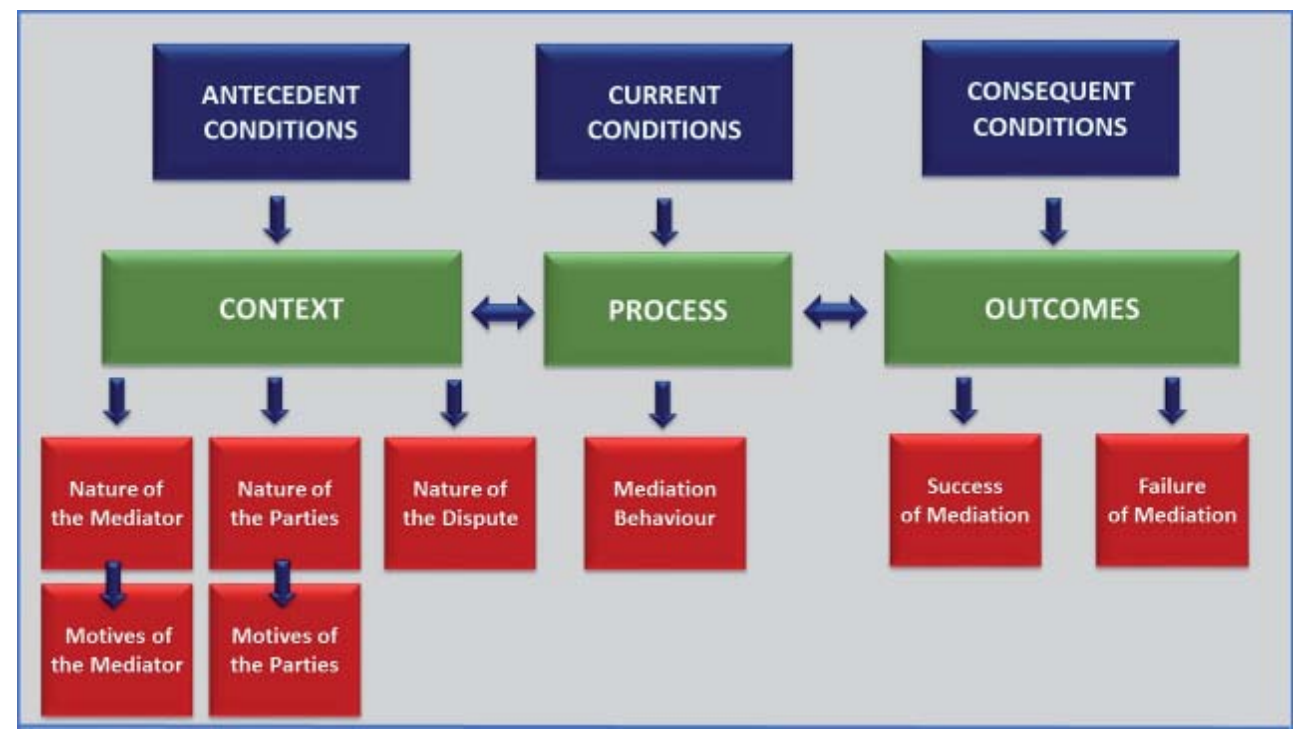

Figure 1. A contingency model of mediation with the distinction of the motives of mediation actors (adapted from Bercovitch and Jackson 2009, p. 37).

In conclusion, the following list of attributes characteristic for mediation in an armed conflict, indicating at the same time the nature of this method, can be presented (Bercovitch and Jackson 2009, pp. 34-35):

- mediation is an extension and continuation of the peaceful process of conflict resolution;

- mediation is based on the intervention of an external actor, i.e. a person, state, organisation, group, in an ongoing conflict between two or more states or other actors;

- mediation is a voluntary, non-violent, non-binding intervention (as opposed to arbitration or military intervention);

- the mediator enters an internal or international conflict to change, resolve, modify or influence the conflict, by using personal and structural measures;

- in the mediation process, the mediator uses ideas, knowledge, resources, his or the interests of the actor he/she represents, at the same time presenting his/her own viewpoint of the conflict or a solution to it; 
- mediation is a voluntary form of conflict management, and parties involved in the conflict have constant control over the effect and process of mediation and they have complete freedom to accept or reject the mediator's proposal;

- mediation is usually appointed ad hoc.

Moreover, the factors that have a significant impact on the course and outcome of the mediation process in an armed conflict are the parties to the conflict and the mediator in the area of the subjective analysis, and the motives of the conflicting parties and mediator in the area of the subject analysis.

\section{Parties of the conflict and mediacy motives}

In traditionally understood armed conflicts, the so-called Clausewitz wars, the states were the main sides of the conflict. In contemporary armed conflicts, there is a large diversity of parties in terms of their legal status, as well as their abilities and resources to conduct military operations. The sides of a conflict are state and non-state actors, such as nations, ethnic groups, rebel military organisations, paramilitary organisations and private security companies with the specifics of a military organisation, self-defence groups or fighters, terrorist organisations, "armies" of local warriors, organised crime and gangs, police/militia units, mercenary units, and demoralised military units (Pawłowski 2007, pp. 351-352; Perrin 2012; Bartnicki 2008, p. 31). Moreover, the analysis of contemporary armed conflicts indicates that the belligerent can be international organisations, for instance, NATO's participation in the intervention against the Islamic State (ISIS) (Gibadło 2017).

The parties in the conflict drive to the mediation have diverse motives. According to Hans Giessmann and Oliver Wils (2011, pp. 189-190), the main motive for them is the conviction that the inclusion of an external actor - a mediator, will serve their interests better and allow for a benefit, rather than keeping the conflict outgoing and unregulated. The benefit is perceived by them in terms of allowing them a position in the conflict, gaining strategic capabilities and military advantage, as well as allowing them to avoid the choice between escalation of the conflict and making concessions (cf. Melin, Gartner and Bercovitch 2013, p. 357; Zartman and Touval 1992, pp. 241-261). 
As Constantine Ruhe (2015, pp. 243-257) claims, the adversaries decide to choose mediation when the assessment of the benefits of its use by the disputants exceeds the purposefulness of continuing the conflict. The determinant of purposefulness is the chance to win in the conflict and the related costs. Upon conducting the analysis of the costs and profits, the parties decide to start mediation when the chances of a military victory are low and the costs of being in a war are significantly higher. However, in a situation when the chances of winning are relatively high, the parties decide to incur even significant costs related to the intensification of their military operations. These costs are not seen by them in the category of unplanned load but are qualified as an outcome of a specific sacrifice. For the necessity of incurring them, the disputants blame the opponent. They inform public opinion that the adversary's actions are highly aggressive and uncompromising, thus forcing them to continue the warfare. The implementation of this manipulation mechanism allows an increase in financing the armed activities to be justified. This technique is used primarily by the weaker party in the conflict. Its implementation results from the actor's conviction that the planned success in the theatre of war will strengthen his position in the conflict in a relatively short time.

In the view of Hans Giessmann and Oliver Wils (2011, p. 194), the factor determining the adversaries for commencement of mediation is the emergence of a deficit in the financing of the rising economic costs of war, which is mostly the result of an intensification of conducting military operations. Yet another important determinant, characteristic primarily of prolonged conflicts, is the infraction of the availability of funds, resources and stable mobilisation of forces at the actors' disposal. Furthermore, a crucial reason for the parties to start mediation is the growing number of civilian losses resulting from the escalation of the conflict, which carries out a risk of reducing the support of political elites, civilians and soldiers for continuing military operations.

William Zartman (2008) points out another motive for convinced parties to agree to mediation, the stalemate situation (the so-called Mutually Hurting Stalemate, MHS). This raises the fear in the adversaries that they are involved in a costly conflict without the possibility of emerging from it victorious. And its further continuation may have disastrous consequences for them. Therefore, the parties start looking for alternative solutions or a way out of the conflict. At this moment, they become ready to negotiate. This radical transformation of their behaviour 
(the way of perceiving through the conflict) reveals that the conflict "matured" to be managed through mediation. This situation is called "ripeness of conflict" (Darby and MacGinty 2008, pp. 22-36).

The parties evaluated the conflict situation as a stalemate based on the subjective feeling of suffering, the manner of defining the impasse, difficulties and expedience of continuing the struggle. On the other hand, this perception consists of the analysis of objectively occurring variables conducted by the disputants, such as data on the amount and nature of losses and physical costs. Moreover, the factor that confirms the "maturity" of the conflict is the fact that the adversaries have a belief in the need to find the so-called way out. However, in the phase of the ongoing impasse, the disputants do not yet have a specific concept of ending the conflict. They are only convinced that the other side presents a similar way of thinking about the conflict in the category of a stalemate situation and is ready to solve it through peaceful means (Figure 2).

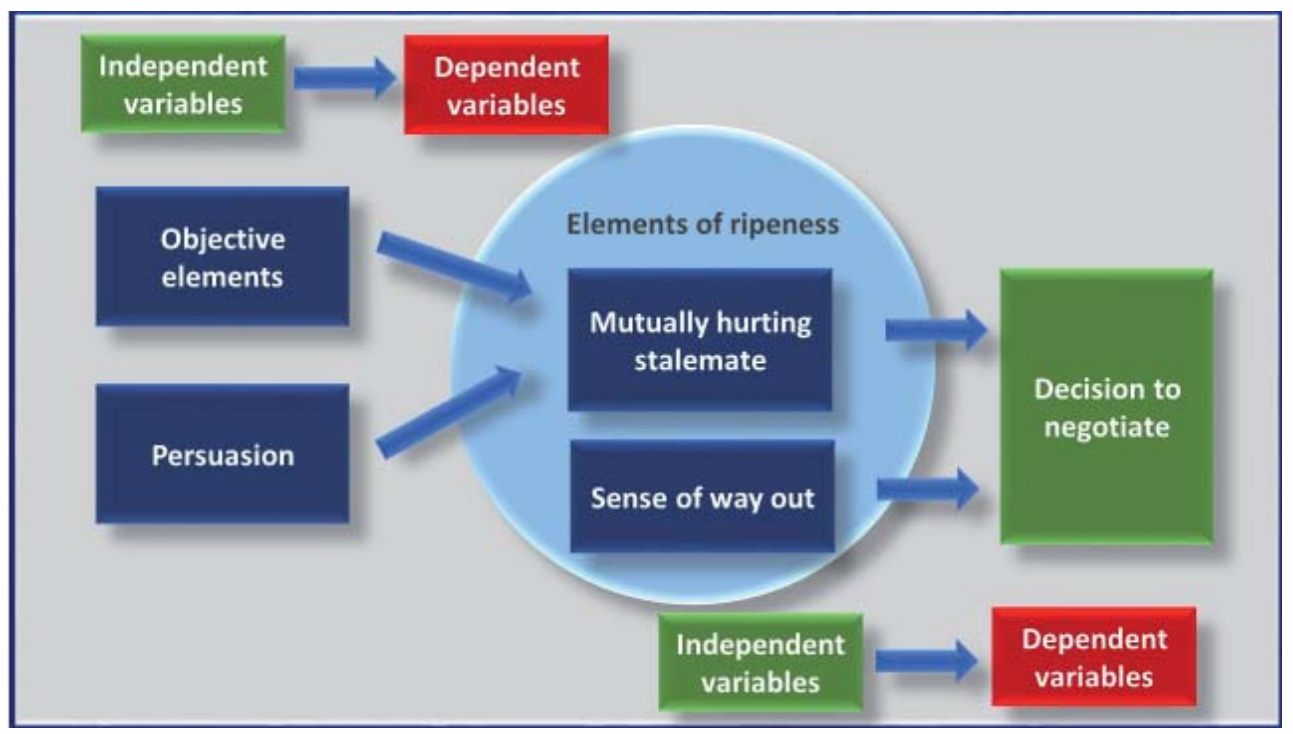

Figure 2. Factors influencing the maturity of the conflict and the decision of the parties to negotiate (adapted from Zartman 2000, p. 230).

The MHS is the main determinant modifying the way the parties perceive the conflict. It leads to the activation of the rational choice mechanism. The adversaries hoping for mediation are convinced that they are making a reasonable and less costly decision as opposed to continuing the war. An expression of their readiness 
to undertake mediation is the establishment of a spokesperson by each party who informs public opinion (or members of the group participating in the conflict), as well as the international community, about the changes introduced in the policy implemented, aimed at initiating a dialogue and resolving the conflict (Zartman 2000, p. 9) $)^{3}$.

In the view of Michael Greig and Patric Regan, the key condition for the occurrence of MHS is the high intensity of the conflict and its long duration. In the initial or early phase of the conflict, the parties usually refrain from mediation, because they are convinced that they will win the war. However, they reject the possibility of using mediation in the late conflict cycle as the costs incurred at this stage of the conflict. Because, in this situation, they do not take into any different option than victory into account (Greig and Regan 2008). In turn, James Wall and Anna Lynn claim that the parties do not resort to mediation in a low-intensity conflict because they are convinced of their ability to solve it themselves (Wall and Lynn 1993, pp. 160-194). The above thesis has been confirmed by the studies of armed conflicts conducted by Jacob Bercovitch and Richard Jackson (2001, pp. 70-71). Their analysis of the relationship between mortality rate and the choice of the conflict resolution method by the parties showed that with a mortality rate below 500 victims, the adversaries preferred negotiations as a method of conflict regulation. However, when the number of fatalities exceeded 10,000 (i.e. when the conflict reached a higher level of intensity), belligerents decided to use mediation.

According to Hans Giessmann and Oliver Wils (2011, p. 190), the parties resort to mediation as they seek to use it as a political strategy. The use of mediation aims to prevent the reduction of public opinion support for the military operations carried out. Their participation in mediation plays the role of a particular message sent by parties to their supporters to inform them about maintaining a strong position in the conflict and working out a new initiative of action. In this view, the commencement of mediation is presented as an opportunity for the parties to obtain more favourable conditions than the current ones undertaken for regulating the conflict. In addition, it enables the actors to gain some time, which is necessary to regroup and strengthen their armed forces and to develop

3 More on the theory of games see Myerson (1997). 
a new war strategy. Furthermore, Giessmann and Wils (2011) point out that the adversaries use mediation as a communication strategy with the international community. This way, the disputants announce that they are ready to accept and respect the international regulations regarding peaceful conflict resolution and start cooperation to solve the conflict. A change in the attitude of the parties is usually met with a favourable reaction from the international community, which is manifested by the cessation or reduction of various forms of pressure applied on the adversaries, such as sanctions aimed at forcing them to end of the conflict.

The pressure of the international community is an important factor motivating the parties to undertake mediation, especially for the actors who depend on international aid and international recognition of them as a belligerent. The pressure may either cause the parties to cooperate to end the conflict or to stiffen the present position, reject the offer of mediation, or even withdraw from the negotiations already started. In order to limit the possibility of the actors resigning from mediation, the international community applies a mechanism consisting of a combination of two types of actions - pressure and benefit (the carrot and stick mechanism). Constraint is most often implemented through various types of sanctions. And benefit takes the form of providing the conflicting party with assistance such as political support, economic and technical aid. It is provided in exchange for the belligerents adapting to the recommendations of the international community regarding the ending of the war (Giessmann and Wils 2011, p. 194; Griffiths and Barnes 2008).

Other motives for the conflict party to join mediation is the opportunity to gain international recognition as a belligerent and strengthen their position and chances on the battlefield, which are significantly lower in relation to the military capabilities possessed by the opponent. This action is taken mostly by non-state actors who are a side in internal conflicts (Giessmann and Wils 2011, p. 191; Clayton 2013; Michael 2015). During the mediation process, an equation between the position of the fighting opposition and the legitimate government is made because according to the rules for conducting mediation, the parties participating in the mediation should be treated in an impartial manner and the mediator should remain in neutral relation to them. In this situation, as pointed out by Molly Melin and Isak Svensson (2009, p. 254), there is a danger of violating the existing international status quo. By entering the mediation, the government indirectly 
accepts the position of the opponent party in the negotiations. Therefore, Melin i Svenssona proposed that the acceptance of mediation should be made by the government only when faced with a supreme number of benefits resulting from resolving the conflict (Walter 2009).

It needs to be highlighted that mediation is chosen by the parties to the conflict among other methods of resolving conflict, because it allows adversaries to "save face" in the meaning of avoiding direct responsibility for participating in negotiations and them ending in fiasco. Involving the mediator in solving the conflict lets the parties place the responsibility for organising the mediation process on him/her. So, in the event mediation fails, they can "save face" and blame the mediator (Giessmann and Wils 2011, p. 191). This strategy is used primarily in conflicts in which the participating actors are highly polarised because of cultural and ethnic differences, existing political systems and forms of social organisation (Bercovitch and Jackson 2001, p. 73).

Upon the above considerations, a catalogue of motives to which the parties of the conflict choose to achieve mediation has been created. These motives include: - securing own interests; - obtaining a significant benefit; - profit and loss analysis; - appearance of a stalemate in the conflict; - using mediation as a political strategy; - using mediation as a communication strategy; - reducing the pressure of the international community; - equalisation of opportunities and positions in the conflict; - using mediation as a "save face" strategy; - using the mediator as a moderator, verifier and guarantor for the implementation of a possible agreement.

\section{The mediator and his motives}

The mediator plays a fundamental role in the mediation process. Kimberlee Kovach (2004, p. 15) defines the mediator as a neutral third person (the socalled intermediary), whose task is to enable the adversaries to start and conduct dialogue, help them identify problems that are crucial for the resolution of the dispute, and advise them in the generation of options (cf. Rau, Sherman and Peppet 2006, p. 337). The mediator's neutrality, as Paweł Waszkiewicz (2014, pp. 163-166) explains, is ensured by his lack of connection to the subject of the dispute and the 
lack of any interest in any particular way of ending the conflict. The mediator's opinions, beliefs or prejudices should not affect the perception of the subject of the dispute nor should they determine the relationship of the fighting parties to possible solutions. The mediator should also be impartial towards the parties to the conflict, i.e. not having any relationship with any of the parties to the conflict, not representing the interests of any of them, not favouring or discriminating or subjecting them to verbal and non-verbal assessment. The task of the mediator is to help each party under the same conditions to find a solution that satisfies both of them. In addition, the mediator should give adversaries the freedom to speak and ask questions related to the subject of the dispute during joint sessions, as well as at individual meetings (Waszkiewicz 2014, pp. 162-163).

According to Elmore Jackson (1952), a party has confidence in a mediator only if she / he is perceived as impartial. Similarly, Barcik and Sorogosz (2007, p. 436) stress that the mediator's impartiality is a crucial factor in facilitating communication between the parties, the creation of the so-called communication channel. On the other hand, Guy Faure (1989, pp. 418-419; cf. Touval 1985, pp. 373-378) argues that mediators are accepted by the adversaries not because of their impartiality but because of their ability to influence, protect or extend the interests of each party in conflict. Furthermore, Marieke Kleiboer (1996, p. 370) claims that a certain degree of bias is acceptable as it can be helpful in conducting mediation. When the mediator proves his support to the stronger party, he will be more inclined to accept his proposals for dispute resolution, and the weaker party will be able to use the mediator's existing influence to influence the stronger side in this way. This view goes in line with Andrew Kydd (2003, pp. 597-598) who argues that the total disinterestedness of the mediator can be perceived by the parties to the conflict as a lack of credibility, especially when the intermediary is focused only on resolving the conflict and has limited resources to convince the parties to make concessions.

Due to the fact that the mediation is a voluntary process, i.e. the parties voluntarily decide to join $i^{4}$, mediators cannot mediate unless they are perceived as reasonable, acceptable, knowledgeable, and able to secure the trust and

4 More on the principle of voluntarism cf. Waszkiewicz (2014, pp. 159-162); Coolidge (https://imimediation.org/imi-code-of-professional-conduct) and The European Code of Conduct for Mediators (ec.europa.eu/civiljustice/adr/adr_ec_code_conduct_en.pdf). 
cooperation of the disputants (Bercovich and Houston 1996, pp. 12-13). In the mediation process the mediator acts as a peacemaker, i.e. he or she not only takes a position between the parties, but also advises them how to find a satisfactory solution. This function requires active involvement in the process of conducted negotiations, the ability to look at the conflict from a different point of view than the one represented by the parties and creating an atmosphere that facilitates dialogue and the development of creative solutions to the dispute (Nordhelle 2010, p. 27). Therefore, the mediator should have the characteristics designating him or her to conduct mediation: honesty, independence, empathy, patience, flexibility. In addition, the mediator should master other skills fundamental in the mediation process, including paraphrasing, summarising, setting priorities and mediation goals, explaining needs and interests, discharging conflict/tension, expanding the scope of action, going beyond the established conceptual framework of mediation, emphasising common values, distributing the problem to particular aspects, helping the parties in making small concessions, and developing a proposal to resolve the dispute. The mediator should demonstrate the ability to create a new view / approach to the problem, overcome the deadlock in the conflict, open a new space for dialogue, convince the parties to participate actively in the negotiations, and help them find solutions that allow them to have a sense of victory in the mediation process (Fisas, p. 93).

According to Bernard Mayer (2000, p. 263), the key predisposition of mediators for conducting mediation is their extensive knowledge of the conflict environment. They also need to possess significant analytical abilities to accurately identify the parties involved in the conflict, understand the relative power and authority of the people involved in the conflict, assess their behaviour, including the analysis of social acceptance of behaviour, conditions of such reactions, indications of reference groups and support groups for parties to the conflict and recognition of repressed behaviour. It is important to understand the layers of the conflict and the ability to find a field for negotiation where parties can work together to resolve a conflict. In addition, the mediator should have broad communication skills, manifested, among others, in the coherence and clarity of the message, because it allows the parties to understand the information conveyed to them unequivocally. 
The choosing of the mediator by parties to the conflict is significantly influenced by his/her social prestige and experience in conducting negotiations. These factors are perceived by the disputants as significant for achieving their preferred results from the mediation. Therefore, a person who is already experienced in successful mediation in armed conflicts rather than building his experience in this field will be accepted more readily by the belligerents (Greig and Regan 2008). Nevertheless, there are situations when a specialised mediator can be the reason for rejecting mediation. This happens when the parties to the conflict have a lot to lose in solving it. In this situation, the mediator can be perceived as restricting the party's freedom to determine the conditions for resolving the conflict (Maundi, Zartman, Khadiagala, and Nuamah 2006).

In mediation in armed conflicts, the role of the mediator may be taken by a state (or a group of several states), international organisations (e.g. the International Committee of the Red Cross), or individuals (including those acting on behalf of international organisations) (Barcik and Srogosz 2007, p. 436). For example, the United States acted as a mediator in the negotiations regarding the Arab-Israeli dispute, concluded with the signing of the Egyptian-Israeli treaty at Camp David in 1978. Algeria also mediated in the dispute between the US and Iran regarding the release of US hostages in Tehran in 1981 (Barcik and Srogosz 2007, p. 436). The European Union also played the role of mediator in the Orange Revolution in Ukraine in 2004, which is an example of an international organisation's involvement in the mediation (Herrberg 2012, pp. 21-23). Other examples of international organisations include the participation of OSCE in negotiations in the Ukrainian conflict (Sticher 2015, p. 10) and the mediation of the UN and the Arab League in the Syrian conflict (Lundgren 2016, p. 274-277).

In turn, individuals acting as mediators tend to be people of high social and professional prestige acting individually, but most often representing states, governmental or non-governmental organisations. They may be former presidents of states, recognised politicians, diplomats or religious leaders (Baumann and Clayton 2017), for example Richard Holbrook played the role of a mediator in a threesided conflict, between the Federal Republic of Yugoslavia, Croatia and Bosnia and Herzegovina, taken up to end the war in Bosnia (Camisar, Diechtiareff, Letica, and Switzer 2005). Nicolas Sarkozy, the former president of France, also participated as a mediator in the Russian-Georgian conflict in 2008 (Herrberg 2012, pp. 21-23). 
In addition, non-governmental organisations (NGOs) may play the role of mediators. Their participation is advantageous due to their greater flexibility in action and lower level of political dependence resulting from relations with other entities, i.e. state or governmental organisations (IOs). However, due to their limited capacity, the ability and the means to carry out mediation activities, NGOs are most often not included in the formal mediation process. They participate in a parallel mediation process in which civil societies and key stakeholders are involved. They may also prepare the grounds for mediation for other actors. An example of the participation of NGOs in mediation is the Center for Humanitarian Dialogue, which assisted mediator Kofi Annan in solving the electoral crisis in Keni in 2007-2008 (Baumann and Clayton 2017).

Other actors taking the role of mediator may be faith-based leaders, representatives of ethnic communities, women's groups, youth organisations, civil society groups, and citizen networks. These mediations are called "local- alternatives" mediations and their operation requires different forms of engagement, such as "moving mediation away from international hotels and heavy compounds and into places where people actually live in a local community" (Independent Commission on Multilateralism 2016).

It should be noted that the mediator is guided by diverse motives in mediation. According to J. Bercovitch and R. Jackson (2009), they include:

- an unambiguous mandate to participate in mediation;

- willingness to resolve the conflict, as its continuation may lead to a severe violation of political interests (the state or organisation represented by the mediator);

- a direct invitation to conduct mediation sent by one or both parties to the conflict;

- striving to maintain the structure whose entity is the represented subject (e.g. mediation by the United States in the dispute between Greece and Turkey, a two-valued NATO member-state);

- perception of mediation as a way of prolonging and strengthening the influence by creating a sense of being indispensable or feeling grateful for the striving involvement;

- participation in mediation aimed at its resolution or inhibition considering potential benefits;

- treating mediation as a policy instrument that allows the mediator to achieve his or her own interests without arousing too much opposition.

(Bercovitch, Jackson 2009, p. 41) 
According to Barcik and Srogosz (2007, pp. 435-436), the primary goal of the mediator's action is to persuade the opponents to negotiate. Therefore, the mediator should actively participate in negotiations that should end in the mediator presenting a compromise acceptable to the adversaries of the dispute. Similarly, Konrad Pawłowski (2007, p. 368) notes that the task of the mediator is to soften the opposing positions of the parties, to persuade them to work out a proposal for the peaceful resolution of the dispute and its adoption. Therefore, it is important that the mediator participate in the diplomatic negotiations conducted by the parties to the dispute. The mediator directs the process of diplomatic negotiations, actively cooperates with the parties discussing the proposals for ending the dispute, as well as presents his or her own concepts for solving the dispute. The mediator should encourage the parties to intensively engage in the search for an optimal solution and to concentrate their efforts on the possibilities of reaching an agreement. The mediator performs the following tasks:

- organising parties' meetings;

- agreeing on the mediation procedure;

- helping the parties express emotions and expectations;

- helping in formulating proposals of solutions;

- not resolving the dispute;

- not giving an opinion (even on the parties' request);

- not representing any of the parties;

- he or she cannot be appointed as a witness in a given case.

(Bargiel-Matuszewicz 2007, pp. 81-82)

Kyle Beardsley (2011) points to the public and private interests of the mediator in conducting mediation. Collective benefit is related to ensuring the stabilisation of the international system and reducing the negative externalities of the conflict. Private interest concerns the reduction of the possibility of the conflict spreading to other countries or regions (e.g. the transfer of conflict due to a wave of migration) abandoning the humanitarian crisis, which is a significant factor in the mediation carried out by intergovernmental and nongovernmental organisations. Beardsley claims that a third party is more likely to mediate when the intensity of the conflict is high. The stimulus to action is the inhibition of the potential possibility of the conflict spreading and the reduction of high humanitarian costs. 
Michael Greig and Patrick Regan (2008) stated that the parties undertake mediation mostly when they have their own interests in it. In the case of states, they are more likely to mediate in a conflict in the neighbouring state than to engage in resolving conflicts in far-away countries. However, Croker, Hampson and Aall (2003) argue that the mediator decides to undertake mediation upon the analysis of his or her operational abilities, including political, strategic and diplomatic as well as having relations that allow all sides of the conflict to be influenced.

The motivations of the mediator influence the reception and the role played by him or her in the conflict. According to Zartman and Touval (1985), the mediator acts as a communicator, formulator or manipulator. Joseph Stulberg (1987) points to the roles of a catalyst, educator, translator, resource-expander, bearer of bad news, agent of reality, and scapegoat. Vincenc Fisas, based on the research carried out by Chris Mitchell, presents a comprehensive list of roles, which has been included in the table below (Table 1.).

\begin{tabular}{|l|l|}
\hline Roles of mediator & Task and functions \\
\hline Explores & $\begin{array}{l}\text { Explores the possibilities for initiating a process, confirms to the parties that } \\
\text { they are all willing to start, even being able to make some suggestions }\end{array}$ \\
\hline Convener & $\begin{array}{l}\text { Is the one who formally invites the parties to start negotiations. Could convene } \\
\text { a ceasefire, the start of conversations, etc. Offers facilities and resources. }\end{array}$ \\
\hline Decoupler & Eliminates external interference and ensures nobody meddles \\
\hline Unifier & Helps overcome internal divisions \\
\hline Reassurer & $\begin{array}{l}\text { Prepares the parties to be able to negotiate in the best conditions and correct } \\
\text { the inequalities that could exist between them }\end{array}$ \\
\hline Envisioner & Offers new information, ideas, theories and options to adversaries \\
\hline Guarantor & $\begin{array}{l}\text { Guarantees to the adversaries that they are not going to suffer exaggerated } \\
\text { costs due to entering a mediation process. Offers securities against a possible } \\
\text { breakdown in the process }\end{array}$ \\
\hline Facilitator & $\begin{array}{l}\text { Plays various roles throughout the process, such as chairing meetings, } \\
\text { interpreting positions and responses, etc, acting as moderator }\end{array}$ \\
\hline Legitimizer & Helps adversaries to accept the process and the result obtained. \\
\hline Enskiller & $\begin{array}{l}\text { Offers additional resources to help the adversaries to find a solution in which } \\
\text { everybody wins. }\end{array}$ \\
\hline Verifier & Verifies and checks that agreements are complied with \\
\hline Implementer & $\begin{array}{l}\text { Controls the behaviour of the parties after the agreement and imposes } \\
\text { sanctions if the agreements are not complied with }\end{array}$ \\
\hline Reconciler & $\begin{array}{l}\text { Has a long-term task, which consists of correcting negative attitudes, } \\
\text { stereotypes and images that tend to exist between adversaries }\end{array}$ \\
\hline
\end{tabular}

Table 1. The role of the mediator in the mediation process (adapted from Fisas) 
In addition, Fisas notes that mediation is a complex process in which the mediator works together with a team of negotiators cooperating with him, carrying out various tasks depending on the existing conditions. Therefore, the mediator can play one role or several roles depending on the situation and the need. The course of the mediation and, to a significant extent, its result depends on how the mediator fulfills his or her roles. Therefore, it is important for the mediator to maintain transparency when performing the function and not to take roles that are mutually exclusive, such as a coach of the armed group preparing for the participation in negotiations and the main interviewer between the conflicting sides of the conflict. Fisas also emphasises that the key element of mediation is the selection of the right people or institutions to perform particular roles, i.e. the creation of a specific network of people acting as facilitators and fulfilling the roles depicted above.

\section{Conclusions}

Mediation is one of the most commonly used methods in solving armed conflicts, mainly due to providing the interested parties with the flexibility to freely decide about participation in mediation, the choice of a mediator, and acceptance or rejection of the conditions of conflict resolved by the parties established during the mediation process. Mediation is also distinguished by the low cost of conducting the process in comparison with other methods involving third party intervention in the conflict, i.e. arbitration or military intervention.

The nature of mediation is the peaceful involvement of an external actor, the mediator in the conflict, in order to resolve the dispute between the parties in armed conflict. The purpose of mediation is to change the perception or behaviour of the parties without resorting to physical violence or calling on the legal authority, and helping them in communicating and negotiating disputable issues to make them reach a satisfactory two-sided agreement.

Mediation is notable for the following attributes:

- mediation is the extension and continuation of the peaceful process of conflict resolution; 
- mediation is based on the peaceful intervention of an external entity - mediator (i.e. a person, state, organisation) in an ongoing conflict between two or more states or other actors;

- the mediator's intervention must be agreed by the parties to the conflict, it cannot be imposed on them;

- mediation is a voluntary, non-violent, non-binding intervention (as opposed to arbitration or military intervention);

- the mediator enters the internal or international conflict to change, resolve, modify or influence the conflict by using personal and structural measures;

- in the mediation, the mediator uses process ideas, knowledge, resources, his/ her or the interests of the entity (state, organisation) he/she represents, at the same time presenting his/her own viewpoint of the conflict or a solution to it;

- mediation is a voluntary form of conflict management, and parties involved in the conflict have constant control over the effect and process of the mediation and have complete freedom to accept or reject the mediator's proposals;

- mediation is usually appointed ad hoc.

The main factors affecting the nature, course and outcome of mediation are its actors, namely the parties to the conflict and the mediator, as well as their motives. In contemporary armed conflicts, the warring parties are both state and non-state actors. The motives that adversaries most often use when choosing mediation as a tool to regulate the conflict are:

- ensuring their own goals are achieved;

- obtaining a significant benefit;

- profit and loss analysis;

- appearance of a stalemate in the conflict and working towards breaking through it;

- using mediation as a political strategy;

- using mediation as a communication strategy;

- reducing the pressure of the international community (building a positive image, receiving benefits);

- balancing the opportunities and positions in the conflict (potential asymmetry of the sides to the conflict, different international law status of the parties);

- using mediation as a "save face" strategy;

- using the mediator as a moderator, verifier and guarantor for the implementation of a possible agreement. 
A mediator may be an individual, a state, an international governmental or nongovernmental organisation, or other entities, including representatives of the local community. The main motives of the mediator in the conflict are:

- an unambiguous mandate to participate in the mediation;

- willingness to resolve the conflict by persuading the parties to begin communicating and negotiating the regulations of the disputable issues;

- willingness to resolve the conflict, as its continuation may lead to a severe violation of the political interests of the state or organisation represented by the mediator;

- direct invitation to conduct mediation sent by one or both parties to the conflict;

- striving to maintain the structure which the represented subject is a part of (e.g. mediation done by the United States in the dispute between Greece and Turkey, two valued NATO member-states);

- perception of mediation as a way of prolonging and strengthening the influence by creating a sense of being indispensable or feeling grateful for the involvement in the process;

- participation in mediation aimed at conflict resolution or inhibition, taking into consideration the potential benefits;

- treating mediation as a policy instrument allowing the mediator to achieve his or her own interests without arousing too much opposition.

- public and private interest;

- having the ability, including political, strategic, diplomatic and relations, to influence the sides of the conflict.

The motives for mediation presented by the parties to the conflict and the mediator influence the shape of the mediation process. They affect the actors' defining behaviour in the mediation process, adopting specific roles, determining the areas of negotiation, and determining the level of involvement. The strong coupling between mediation actors and the motives presented by them affects the result of mediation - its success or failure. 


\section{References}

Barcik, J., Srogosz, T., 2007. Prawo międzynarodowe publiczne. Wydawnictwo C.H. Beck, Warsaw.

Bargiel-Matuszewicz, K., 2007. Negocjacje i mediacje. Polskie Wydawnictwo Ekonomiczne, Warsaw.

Bartnicki, A. (ed.), 2008. Konflikty wspótczesnego świata. PWN, Warsaw.

Baumann, J. and Clayton, G., 2017. Mediation in violent conflict. In CSS Analyses in Security Policy, 211. [online] Available from: http://www.css.ethz.ch/content/dam/ ethz/special-interest/gess/cis/center-for-securities-studies/pdfs/CSSAnalyse211EN.pdf [Accessed 27 Oct 2017].

Beardsley, K., 2011. The Mediation Dilemma. Cornel University Press, New York.

Bercovich, J. and Houston, A., 1996. The study of international mediation: Theoretical issues and empirical evidence. In J. Bercovich (ed.), Resolving International Conflicts: The Theory and Practice of Mediation. Lynne Reinner, Boulder-London.

Bercovitch J. and Derouen, K. Jr., 2004. Mediation in Internationalized Ethnic Conflicts: Assessing the Determinants of a Successful Process. Sage Journals, 30(2), 147-170.

Bercovitch, J., Jackson R., 2009. Conflict Resolution in the Twenty-first Century. University of Michigan Press, Ann Arbor.

Bercovitch, J. and Jackson, R., 2001. Negotiation or Mediation? An Exploration of Factors Affecting the Choice of Conflict Management in International Conflict. Negotiation Journal, 17(1), 59-77.

Bercovitch, J., 1994. The structure and diversity of mediation in international relations.

In J. Bercovitch (ed.), Mediation in International Relation. Multiple Approaches to Conflict, Macmillan, London.

Bühring-Uhle, Ch., 1996. Arbitration and Mediation in International Business. Kluwer Law International, The Hague/London/Boston.

Camisar, A., Diechtiareff, B., Letica, B., and Switzer, C., 2005. An Analysis of the Dayton Negotiations and Peace Accords. Final Research Paper, The Fletcher School of Law and Diplomacy. [online] Available from: http://ocw.tufts.edu/data/12/244825.pdf [Accessed 27 Oct 2017].

Carment, D. P. and James, P., 2000. Explaining third-party intervention in ethnic conflict: theory and evidence. Nations and Nationalism, 6 (2), 173-202.

Charter of United Nations, [online] Available from:http://www.unic.un.org.pl/dokumenty/ karta_onz.php/ [Accessed 20 Oct 2017].

Clayton, G., 2013. Relative rebel strength and the onset and outcome of civil war mediation. Journal of Peace Research, 50(5), 609-622.

Coolidge, J.C., IMI Code of Professional Conduct. International Mediation Institute, [online] Available from: https://imimediation.org/imi-code-of-professional-conduct [Accesed 25 Oct 2017]. 
Cortright, D. and Lopez, G.A. (eds), 2000. The Sanction Decade. Lynne Reinner Publishers, Boulder-London.

Cortright, D. and Lopez, G.A. (eds), 2002. Sanction and the Challenges to UN Action. Lynne Reinner Publishers, Boulder-London.

Crocker, C.A., Hampson, F.O. and Aall, P.R., 2003. Ready for prime time: the when, who and way of international mediation. Negotiation Journal, 19(2), 151-167.

Eriksson, L., 2011. Rational Choice Theory: Potential and Limits. Palgrave Mac Millan, New York.

Faure, G.O., 1989. The mediators as third negotiators. In E. Mautner-Markhof (ed.), Process of International Negotiations. Westview, Boulder.

Fisas, V., Mediation in armed conflicts. [online] Available from: http://escolapau.uab.cat/ img/programas/procesos/mediation_armed.pdf [Accessed 21 Oct 2017].

Folberg, J., Golanna, D., Kloppenberg, W., and Stipanowich, T., 2005. Resolving Disputes. Theory, Practice and Law. Wolters Kluwer Law \& Business, New York.

Gent, S. and Shannon, M., 2010. The effectiveness of international arbitration and adjudication: Getting into a bind. Journal of Politics, 72(2), 366-380.

Gibadło, L. 2017. Walka z ISIS po szczycie NATO. „Eliminacja” zamiast „wojny na wyczerpanie”. Defence24, 31 May. [online] Available from: http:// defence24.pl/walkaz-isis-po-szczycie-nato-eliminacja-zamiast-wojny-na-wyczerpanie [Accessed 23 Oct 2017].

Giessmann, H.J. and Wils, O., 2011. Seeking Compromise? Mediation Through the Eyes of Conflict Parties, [online] Available from: http://peacemaker.un.org/sites/peacemaker. un.org/files/Seeking\%20Compromise_BerghofFoundation\%202011_0.pdf [Accessed 23 Oct 2017].

Greig, J.M. and Regan, P.M., 2008. When do they say yes? An analysis of the willingness to offer and accept mediation in civil wars. International Studies Quarterly, 52(4), 759-781.

Griffiths, A. and Barnes, C., 2008. Powers of persuasion: Incentives, sanctions and conditionality in peacemaking. Accord Coalition Resource, 19, London.

Herrberg, A., 2012. International Peace Mediation: A New Crossroads for the European Union. DCAF Brussels - ISIS Europe 2012.

Independent Commission on Multilateralism, 2016. Armed Conflict: Mediation, Conciliation, and Peacekeeping, [online] Available from: https://www.icm2016.org/ IMG/pdf/armed_conflict_discussion_paper-2.pdf [Accessed 20 Oct 2017).

Jackson, E., 1952. Meeting in Minds. A Way to Peace Through Mediation. McGraw-Hill, New York.

Kleiboer, M., 1996. Understanding success and failure of international mediation. Journal for Conflict Resolution, 40(2), 360-389.

Kovach, K., 2004. Mediation. Principle and Practice. Third edition, Saint Paul. 
Kydd, A., 2003. Which side are you on? Bias, credibility and mediation. American Journal of Political Science, 47(7).

Lundgren, M., 2016. Mediation in Syria: Initiatives, strategies, and obstacles, 2011-2016. Contemporary Security Policy, 37(2), 273-288.

Matheson, M.J., 2006. Council UNBound. United States Institute of Peace Press, Washington D.C.

Maundi, M., Zartman, W., Khadiagala, G., and Nuamah, K., 2006. Getting in: Mediators' Entry into the Settelment of African Conflicts. United State Institute of Peace, Washington DC.

Mayer, B., 2000. The Dynamic of Conflict Resolution. Jossey-Bass, San Francisco.

Melin, M. and Koch, M., 2009. Jumping into the fray: Alliances, power, institutions, and the timing of conflict expansion. International Interactions, 35(3), 1-27.

Melin, M. and Svensson, I., 2009. Incentives for talking: Accepting mediation in international and civil wars. International Interaction, 35, 249-271.

Melin, M.M., Gartner, S.S., and Bercovitch, J., 2013. Fear of rejection: The puzzle of unaccepted mediation offers in international conflict. Conflict Management and Peace Science, 30(4), 354-368.

Michael, G.J., 2015. Rebels at the gates: Civil war, battle locations, movement, and openings -for mediation. International Studies Quarterly, 59(4), 680-693.

Miłosz, S., 1996. Środki i Metody Pokojowego Załatwiania Sporów Międzynarodowych. Akademia Obrony Narodowej, Warsaw.

Miranda, A., 2014. The origins of mediation and the A.D.R. tools. In A. Miranda (ed.), Mediation in Europe at the cross-road of different legal cultures. Arcane, Rome.

Mitchell, S.M. and Powell E.J., 2011. Domestic Law Goes Global: Legal Traditions and International Courts. Cambridge University Press, Cambridge.

Moore, Ch.W., 2012. Mediacje: Praktyczne Strategie Rozwiązywania Konfliktów. Oficyna, Warsaw.

Moore, Ch.W., 2003. The Mediation Process. Practical Strategies for Resolving Conflict. John Wiley \& Sons, San Francisco.

Myerson, R.B., 1997. Game Theory: Analysis of Conflict. Harvard University Press.

Nordhelle, G., 2010. Mediacje. Sztuka Rozwiązywania Konfliktów. FISO, Gdańsk.

Pawłowski,K., 2007.Sporyikonflikty międzynarodowe.In M.Pietraś(ed.), Międzynarodowe stosunki polityczne. Wydawnictwo UMCS, Lublin.

Perrin, B., 2012. Modern Warfare: Armed Groups, Private Militaries, Humanitarian Organizations, and the Law. UUBC Press, Vancouver-Toronto.

Rau, A., Sherman, E., and Peppet S., 2006. Process of dispute resolution. Foundation Press.

Ruhe, C., 2015. Anticipating mediated talks: Predicting the timing of mediation with disaggregated conflict dynamics. Journal of Peace Research, 52(2), 243-257. 
Sarkozy steps up mediation efforts over Georgia, [online] Available from: https://www. euractiv.com/section/global-europe/news/sarkozy-steps-up-mediation-efforts-overgeorgia/ [Accessed 27 Oct 2017].

Sticher, V. (ed.), 2015. Challenges to mediation support in hot wars: Learnings from Syria and Ukraine. Discussion Points of the Mediation Support Network, 7.

Stulberg, J., 1987. Taking Charge/Managing Conflict. D.C. Heath, Lexington.

The European Code of Conduct for Mediators. [online] Available from: ec.europa.eu/ civiljustice/adr/adr_ec_code_conduct_en.pdf [Accesed 25 Oct 2017].

Touval, S., 1985. The Context of mediation. Negotiation Journal, 4 (1), 373-378.

Wall, J. and Lynn, A., 1993. Mediation: A current review. Journal of Conflict Resolution, 37 (1), 160-194.

Walter, B., 2009. Bargaining failure and civil war. Annual Review of Political Science, 12 (1).

Waszkiewicz, P., 2014. Zasady mediacji. In E. Gmurzyńska, R. Morek (eds), Mediacje. Teoria i praktyka, Wolters Kluwer, Warszawa 2014.

Young, O., 1967. The Intermediaries. Third Parties in International Crises. Princeton University Press, Princeton 1967.

Zartman, I.W., 2000. Ripeness: The hurting stalemate and beyond. In P.C. Stern and D. Druckman (eds), International Conflict Resolution after the Cold War. National Academies Press, Washington DC, 225-250.

Zartman, I.W. and Touval, S., 2006. Mediation: The role of third-party diplomacy and informal peacemaking. In S. Brown and K.M. Schraub (eds), Resolving Third World Conflict. United States Institute of Peace Press, Washington, D.C.

Zartman, I.W., 2008. The time of peace initiatives: hurting stalemates and ripe moments. In J. Darby and R. MacGinty (eds), Contemporary Peacemaking: Conflict, Peace Processes and Post-War Reconstruction. Palgrave MacMillan, New York.

Zartman, I.W. and Touval, S., 2006. Mediation: The role of third-party diplomacy and informal peacemaking. In Brown S., Schraub K.M. (eds.) Resolving Third World Conflict. United States Institute of Peace Press, Washington, D.C.

Zartman, I.W. and Touval, S., 1985. International mediation: Conflict resolution and power politics. Journal of Social Issues, 41 (2), 27-45. 